\title{
La prospettiva curiosa in acqua: un nuovo linguaggio anamorfico
}

Michele Russo

Abstract

La rappresentazione delle forme geometriche nell'acqua e la loro percezione visiva è un tema complesso, che coinvolge conoscenze che spaziano dalla geometria alla percezione delle immagini, dalla fisica all'ottica. La deformazione geometrica generata dall'acqua, pur essendo legata al fenomeno fisico della rifrazione, presenta diverse analogie con le immagini anamorfiche: da un lato la dinamica variazione della forma in funzione del punto di vista, dall'altro la ricerca della corretta visione della realtà e il ruolo che essa assume dal punto di vista comunicativo.

Attraverso un percorso di analisi critica sullo sviluppo delle immagini anamorfiche nella storia fino ai giorni nostri, questa ricerca pone le prime basi per uno studio sui criteri geometrici di trasformazione delle forme geometriche piane nell'acqua. Partendo da una sperimentazione basata sulla simulazione e l'osservazione della deformazione, ne viene analizzato il principio geometrico, proponendo la costruzione di immagini che prevedano l'effetto deformante dell'acqua da un particolare punto di vista. La finalità della ricerca è quella di definire sperimentalmente un metodo di costruzione di immagini anamorfiche in acqua, mostrando l'integrazione del fenomeno fisico e percettivo, aprendo nuovi scenari di ricerca trans-disciplinari.

Parole chiave

prospettiva, anamorfosi, acqua, rifrazione, comunicazione.

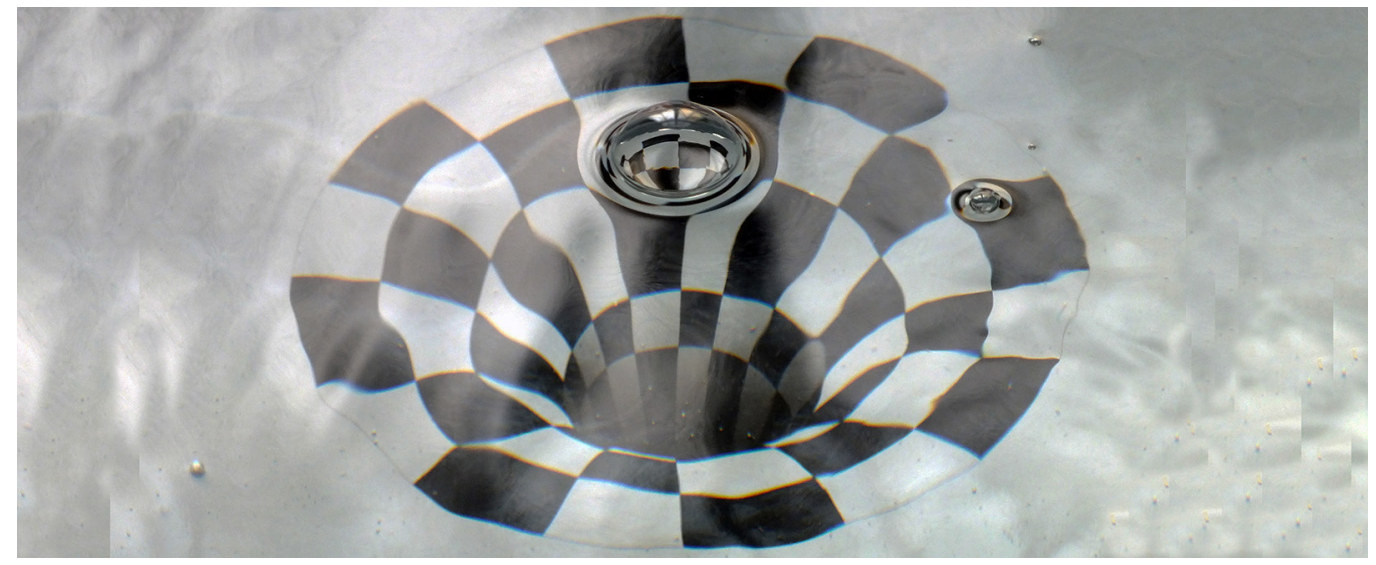




\section{Introduzione}

"C'è una fontana a Granada dove ai visitatori si racconta la storia di un califfo arabo che stava per nominare un Gran Visir: per scegliere invitò i candidati a identificare un oggetto poggiato o galleggiante in acque poco profonde. Tutti tranne uno dissero subito che si trattava di un'arancia. Uno, invece, prima la raccolse, e identificandola come mezza arancia, ottenne la promozione" [Wright 1983, p. 24]. La particolare relazione esistente fra le forme geometriche in acqua e l'uomo determina una labilità nella visione percettiva, fondata su un sistema figurativo e mentale che può trasportarci verso un mondo in cui la dicotomia fra regola e disordine convivono [Zolla 1996, p. 128]. Questa alterazione presenta delle analogie con la deformazione delle forme geometriche operata dalla anamorfosi, spostando l'attenzione da un lato verso la "corretta visione" e la "soggettivazione dello sguardo", dall'altro stimolando la curiosità e la fruizione cinetica nello spazio, alla ricerca della risolutiva angolazione interpretativa [De Rosa, D'Acunto 2002].

In questo processo itinerante, la prospettiva rappresenta il principale strumento di analisi dei fenomeni deformativi, nonché la chiave di volta per la loro comprensione e traduzione in una unica spazialità controllata e prevedibile. Le immagini anamorfiche instaurano una particolare relazione con lo spazio, sia esso urbano o architettonico, trasformandolo in un luogo narrante, fruibile e fruito secondo una dinamica direzionale. La loro crescente diffusione come strumento di comunicazione e la loro ibridazione con il mondo acquatico può arrivare a definire nuovi linguaggi, a patto che ne venga compreso sia il ruolo comunicativo che il processo di costruzione prospettica fuori e dentro l'acqua.

Partendo da una sintetica descrizione dello sviluppo della anamorfosi nella storia, con particolare attenzione alle anamorfosi dirette, viene illustrata una prima sperimentazione che mette in luce le relazioni geometriche e ottiche delle immagini anamorfiche piane in acqua, iniziando un percorso di analisi del linguaggio delle forme geometriche sommerse e del loro modo di percepirle, anticipando possibili scenari trans-disciplinari.

Fig. I. Schema qualitativo dell'uso dell'anamorfosi nella storia, rispetto al ruolo, alle forme artistiche e alla diffusione.

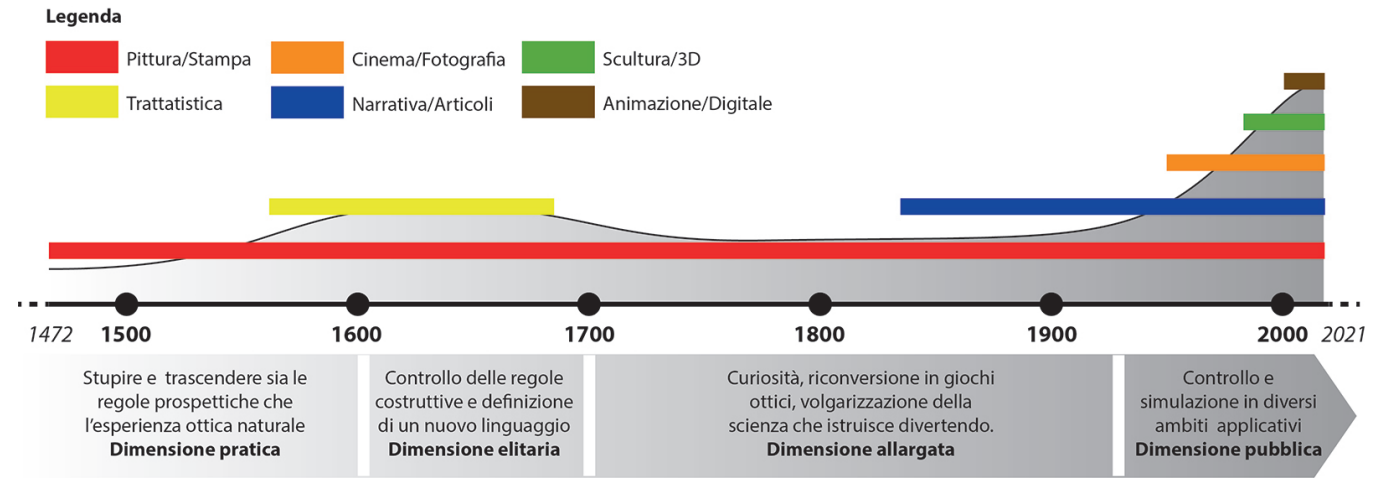

\section{L'anamorfosi come strumento di comunicazione nel tempo}

II termine anamorfosi, di derivazione greca, è composto dal suffisso ává (all'insù, all'indietro, ritorno verso) e $\mu$ legato alle regole della prospettiva lineare (perspectiva artificialis), sia nella genesi che nella relativa fruizione [Gardner 1975, Walker 1981, Hunt et al. 2000, Andersen 2007]. Si fonda sul principio di visione monoculare, secondo il 'cono visivo' della prospettiva classica, presumendo un punto di vista soggettivo che reinscrive la sorgente della visione nel corpo fisico [Collins 1992 p. 73]. Le immagini che ne derivano sono apparentemente distorte, ma si ricompongono e svelano la reale configurazione geometrica secondo un prefissato punto di osservazione (anamorfosi prospettica diretta), oppure mediante il suo riflesso su di una 
superficie convessa a specchio (anamorfosi catottrica) [Andersen 1996]. Nella storia sono definite come una espressione virtuosistica delle leggi prospettiche, rispetto alle quali costituiscono una sorta di prospettiva "curiosa" [Niceron 1638] o di "depravazione" proiettiva [Baltrušaitis 1978].

In questo articolo verrà analizzata esclusivamente l'anamorfosi prospettica diretta, che presenta condizioni ottico-percettive simili a quelle delle forme in acqua. II loro significato è profondamente mutato nella storia delle arti figurative. Partendo dalle prime rappresentazioni di Piero della Francesca (Pala di Brera, 1472) o dagli schizzi leonardeschi (Codice Atlantico, 15 I5), queste rappresentazioni sono passate attraverso diversi livelli di consapevolezza ottico-geometrica e comunicativa. Da iniziale strumento di comunicazione elitaria, sono divenute un linguaggio scientificamente riconosciuto (Anamorphose, Encyclopédie di Diderot e d'Alembert, I75I) fino a essere proposte in molteplici ambiti nel XX secolo (fig. I). La rinascita dell'interesse sulle immagini anamorfiche a partire dagli anni 30 definisce un nuovo scenario culturale, suggerendo diversi temi comunicativi. La definizione di uno o più punti preferenziali di visione esplicita consente al fruitore dell'opera di comprendere meglio l'artefatto, riducendone allo stesso tempo l'accessibilità e la percezione collettiva [De Rosa 2006]. II percorso diviene un obbiettivo progettuale nell'esperienza comunicativa dell'opera, offrendo una trasformazione della forma verso la corretta visione del sistema.
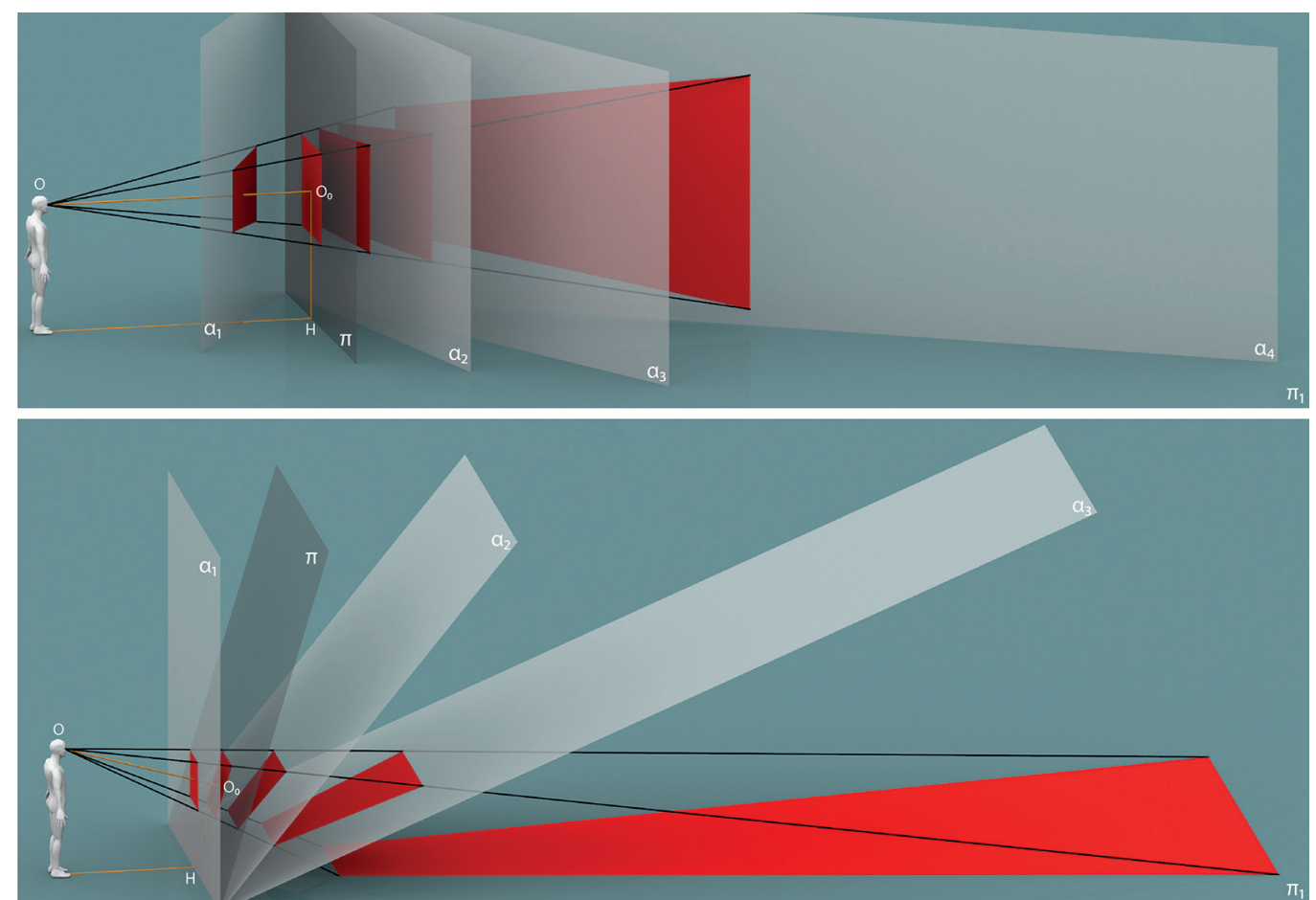

\section{L'anamorfosi nella comunicazione attuale}

Le immagini anamorfiche sono principalmente legate alla progettazione, al design industriale, alla scenografia, alle attività decorative e pubblicitarie. La loro applicazione, per quanto complessa, si riduce spesso a proiezioni orizzontali o verticali, in funzione della scala di rappresentazione (fig. 2).

A scala territoriale, un esempio è fornito dalle opere di Guillaume "Saype" Legros, specialista in land art (fig. 3). A scala urbana invece, accanto al tracciamento delle segnaletiche orizzontali e insegne pubblicitarie [Di Lazzaro, Murra 20 I3], assume un ruolo importante l'attività 
degli street/visual artists, che creano una forte interazione con lo spazio illusorio del disegno e lo spazio urbano. Fra gli artisti (fig. 3) si ricordano Kurt Wenner, Julian Beever [Beveer 20 I 0], Manfred Stader, Edgar Muller, Eduardo Relero, Nikolaj Arndt, Sergio Odeith e Leon Keer.Alcuni di questi, come Vera Bugatti, usano il dipinto anamorfico come attività di denuncia sui temi ambientalisti e sociali. In taluni casi l'anamorfosi esce dal piano, trasformandosi in percorsi urbani caratterizzati da una percezione dinamica delle forme spaziali, come il Giardino effımero di François Abélanet.

Fra le rappresentazioni verticali, i graffiti urbani di Manuel "Peeta" di Rita rappresentano un caso emblematico, accanto all'uso di scritte identificative di edifici architettonici, come il Marta Herford Museum. A scala architettonica è preponderante l'anamorfosi verticale, data l'esigenza di veicolare lo sguardo in determinate direzioni spaziali. Felice Varini [Di Paola et al. 20 I5] utilizza semplici forme geometriche per creare punti di vista preferenziali nelle architetture esistenti, mentre Thomas Quinn utilizza la tipografia anamorfica come strumento di decorazione direzionale.

Una particolare ibridazione fra la proiezione anamorfiche piane e lo spazio 3D consente di studiare il condizionamento delle forme ambientali sulla nostra percezione visiva. Ne sono un esempio la stanza di Ames (1946) e quella di Jan Beutner (1975).

Passando dal piano allo spazio, quest'ultimo diviene itinerario espressivo della forma stessa che sembra volersi liberare, come nelle opere di Sandor Vamos, Alessandro Diddi o Alessandro Panzetti. Le forme nello spazio si decompongono e si ricompongono con differenti

Fig. 3. Opere anamorfiche contemporanee in funzione della scala: G. Legros, Leysin (I): F. Abélanet, Hôtel de Ville, Parigi (2): FVarini, Varcassoni (2); F.Varini, Carcassonne (3); T. Quin , Mannheim (5). Di Rita, (6); M. Murphy (7).
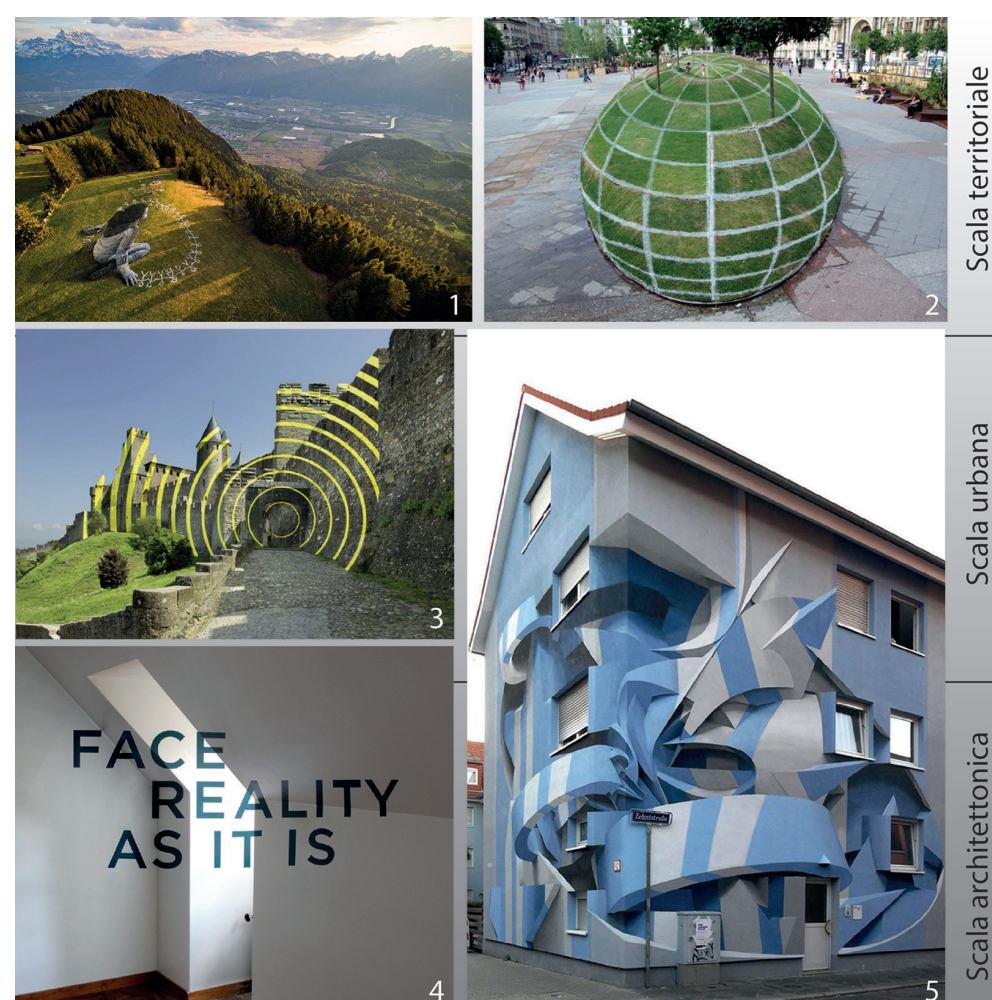

4
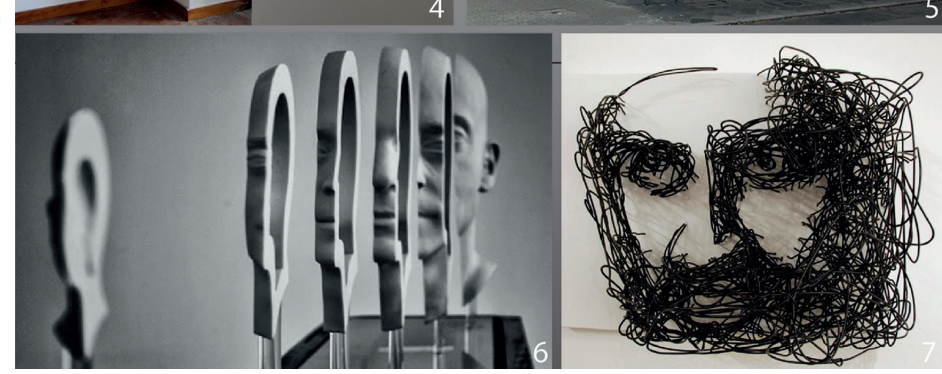
significati, come nelle opere di Michael Murphy, Giovanni Re o Jonty Hurwitz che lavora sui temi dell'ottica [ILLUSION 20I3], esprimendo significati ambivalenti, come nella Ambigram Sculpture di Markus Raetz [Symeonidou 2016].

\section{La rappresentazione anamorfica e l'acqua}

La relazione fra l'acqua e le immagini anamorfiche è poco studiata sia dal punto vista geometrico che percettivo. Eppure, la dinamicità dell'acqua e il suo ruolo di 'piano divisorio' fra due differenti realtà la rende un soggetto privilegiato per le anamorfosi, come si coglie dalle opere di street art (fig. 4). La recente installazione anamorfica Wave (studio d'strict) nel centro di Seul, ad esempio, simula la dinamica del fluido secondo un determinato punto di vista attraverso uno schermo gigantesco.

II suo mancato utilizzo può risiedere nella complessità delle installazioni e nel controllo di un fenomeno prospettico all'interno del fluido. Per quanto riguarda quest'ultimo, i primi studi risalgono agli anni 50, spesso limitati all'analisi geometrica attraverso un solo mezzo omogeneo. Da un quinquennio si sono avviate alcune ricerche sulle relazioni geometriche fra i raggi proiettivi che passano attraverso differenti materiali [Maas 20 I5; Menna 20 I8], anche in relazione alle condizioni ambientali [Agrafotis 20 I8]. Questi studi rappresentano un importante punto di partenza per l'analisi geometrica delle forme immerse in un liquido e la creazione di immagini anamorfiche in acqua.
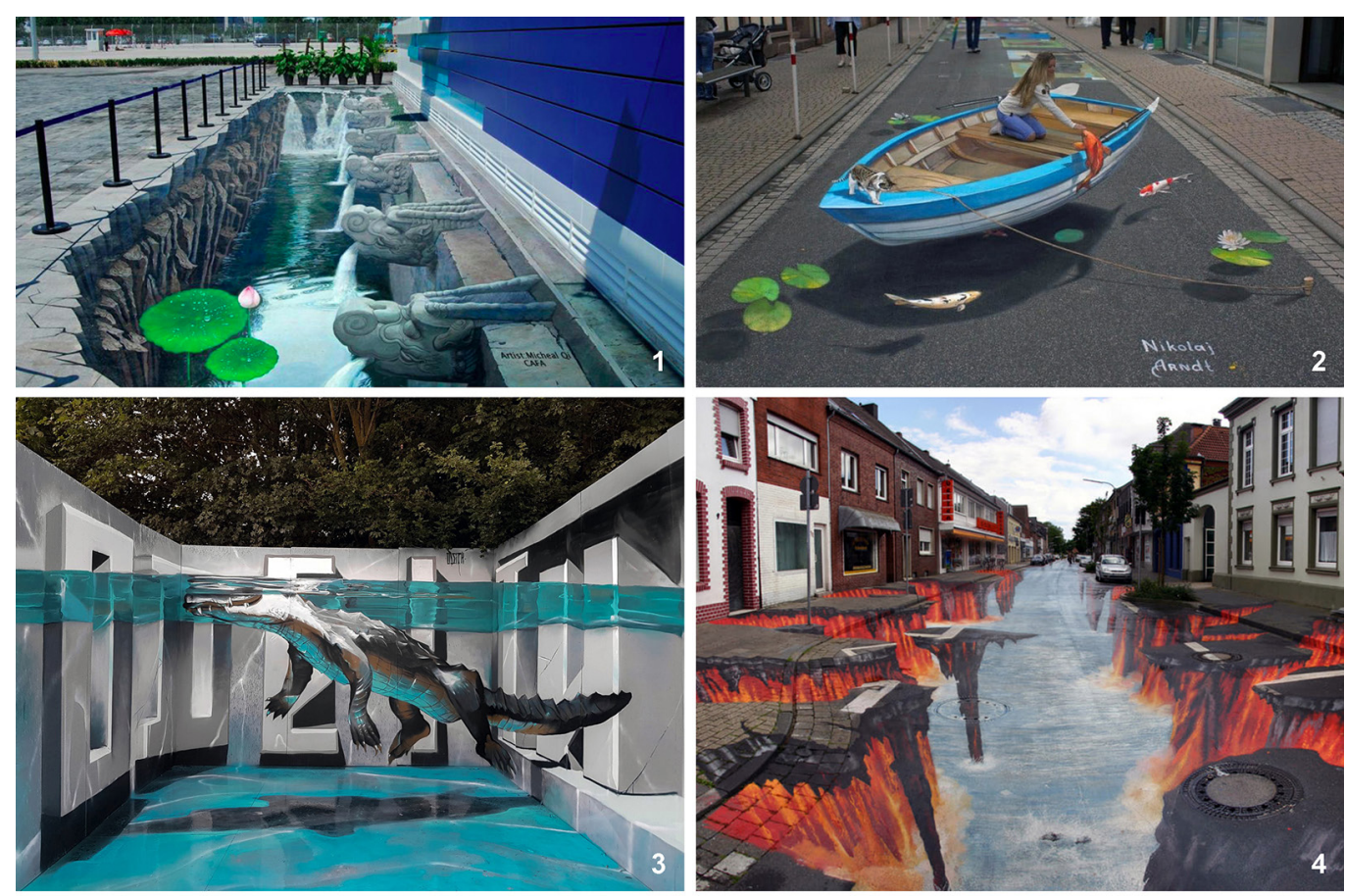

Fig. 4. Esempi di

anamorfosi con l'acqua: dipinto a Barcellona di $M$ Qi Cafa (1); dipinto di N. Arndt (2); dipinto per la Upfest 2018 di S. Odeith (3); dipinto a Geldern (Germania) di E. Muller (4): dipinto a Honolulu (Hawaii) di J. Pugh (5)
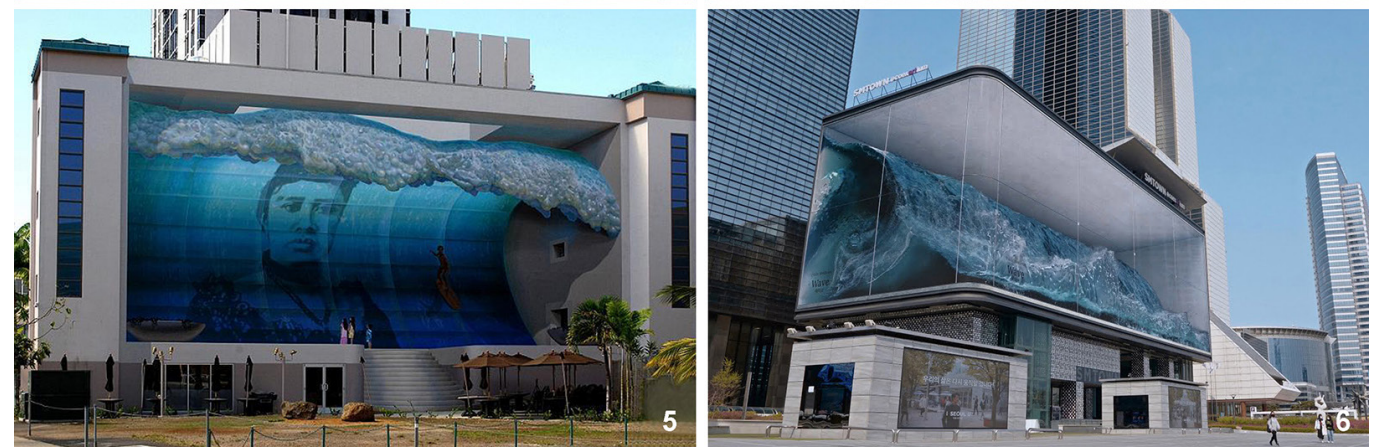


\section{Sperimentazione}

In questa fase l'immagine anamorfica assume il duplice ruolo di obbiettivo percettivo e sistema di verifica del processo. Imponendo la giacitura orizzontale delle immagini in acqua e un asse di visione inclinato, si ricrea quella relazione anamorfica con un unico centro di prospettiva della camera (fig. 2). La coincidenza fra il centro di proiezione prospettica e il centro della fotocamera viene ipotizzata adottando il modello fotogrammetrico semplificato, che prevede un unico centro di proiezione invece del piano nodale anteriore e posteriore. Tale approssimazione è coerente con una fase sperimentale inziale, nella quale l'obbiettivo consiste nella simulazione del sistema visivo umano e non nella acquisizione metrica di geometrie nello spazio. Per le medesime ragioni non viene considerato l'apporto delle componenti distorsive radiali e tangenziali, comunque minime data la centralità del target rispetto al fotogramma.

Nella analisi geometrica bidimensionale (fig. 5) si calcola la rifrazione dei raggi secondo la legge di Snell, considerando il valore dell'aria $(1,000269)$ e dell'acqua $(1,334)$, applicando la seguente equazione:

$$
\frac{\sin \widehat{\beta_{1}}}{\sin \widehat{\beta_{2}}}=1,334
$$

Riportando il problema nello spazio (fig. 6) si deve tenere in conto che ogni punto apparente (punto visto fuori dall'acqua) in realtà subisce una traslazione sul piano e lungo la retta che collega il punto apparente con la proiezione verticale $(H)$ del centro della fotocamera sul piano di giacitura della figura.

Partendo da questa analisi geometrica a priori, viene avviata una fase sperimentale basata sulla simulazione e osservazione del fenomeno, assumendo le seguenti semplificazioni:

I. L'immagine di riferimento o anamorfica giace su un piano orizzontale $\left(\pi_{1}{ }^{\prime}\right)$;

2. L'osservatore sperimenta l'anamorfosi tramite una fotocamera, ignorando la visione binoculare;

3. L'anamorfosi avviene da un solo punto $(O)$, centro nodale della camera, inteso sia come punto di vista preferenziale dell'osservatore e centro della proiezione prospettica.

4. L'asse della camera (direzione di vista) è nadirale al piano dell'acqua o ruotato di $45^{\circ}$. La sperimentazione avviene in due distinte fasi: simulazione virtuale del fenomeno e analisi reale della anamorfosi in acqua. Nella prima fase viene rappresentato in un ambiente di modellazione 3D la relazione prospettica fra una forma geometrica stellare, in vera forma sul piano di quadro (sensore), e le sue due proiezioni ottenute sul fondo di un contenitore vuoto e riempito con $30 \mathrm{~cm}$ di acqua (fig. 7). Dalla sperimentazione si evidenzia una trasformazione minima fra le due proiezioni, giustificata dalle relative semplificazioni: la rotazione di un solo asse del piano di quadro, la perpendicolarità della proiezione dell'asse rispetto alla figura e l'asse ottico passante per il baricentro della figura. Risulta invece evidente lo slittamento nel piano fra le due figure, pari a $12,8 \mathrm{~cm}$. Sulla base della simulazione del processo, si procede a una prova reale. Vengono stampate e introdotte le geometrie simulate senza l'acqua (target rosso) e con l'acqua (target blu) in una vasca, prima vuota e poi riempita con $30 \mathrm{~cm}$ di acqua, pianificando una campagna fotografica con una fotocamera Finepix HS20 EXR, lunghezza focale di 14 $\mathrm{mm}$, secondo specifici parametri di presa (fig. 8). Dal confronto fra le immagini ottenute con e senza l'acqua si evidenzia come il target I senza acqua e il target 2 con l'acqua ripropongono la vera forma geometrica nel sensore, verificata dalla costruzione di un cerchio di verifica, mentre le altre presentano diverse tipologie di deformazione. Si dimostra quindi che la simulazione virtuale è corretta e che, date specifiche condizioni al contorno, sia possibile ottenere una anamorfosi in acqua. 
Fig. 5. Relazione fra la forma acquisita dalla camera (A'B'), i raggi proiettivi di centro $O$ (centro nodale) e la forma in acqua $(A B)$ in configurazione nadirale (sinistra) e ad asse

inclinato (destra) rispetto all'acqua.

Fig. 6. Schemi geometrici sulla relazione camera-

forma geometrica in base alla rotazione dell'asse della camera.
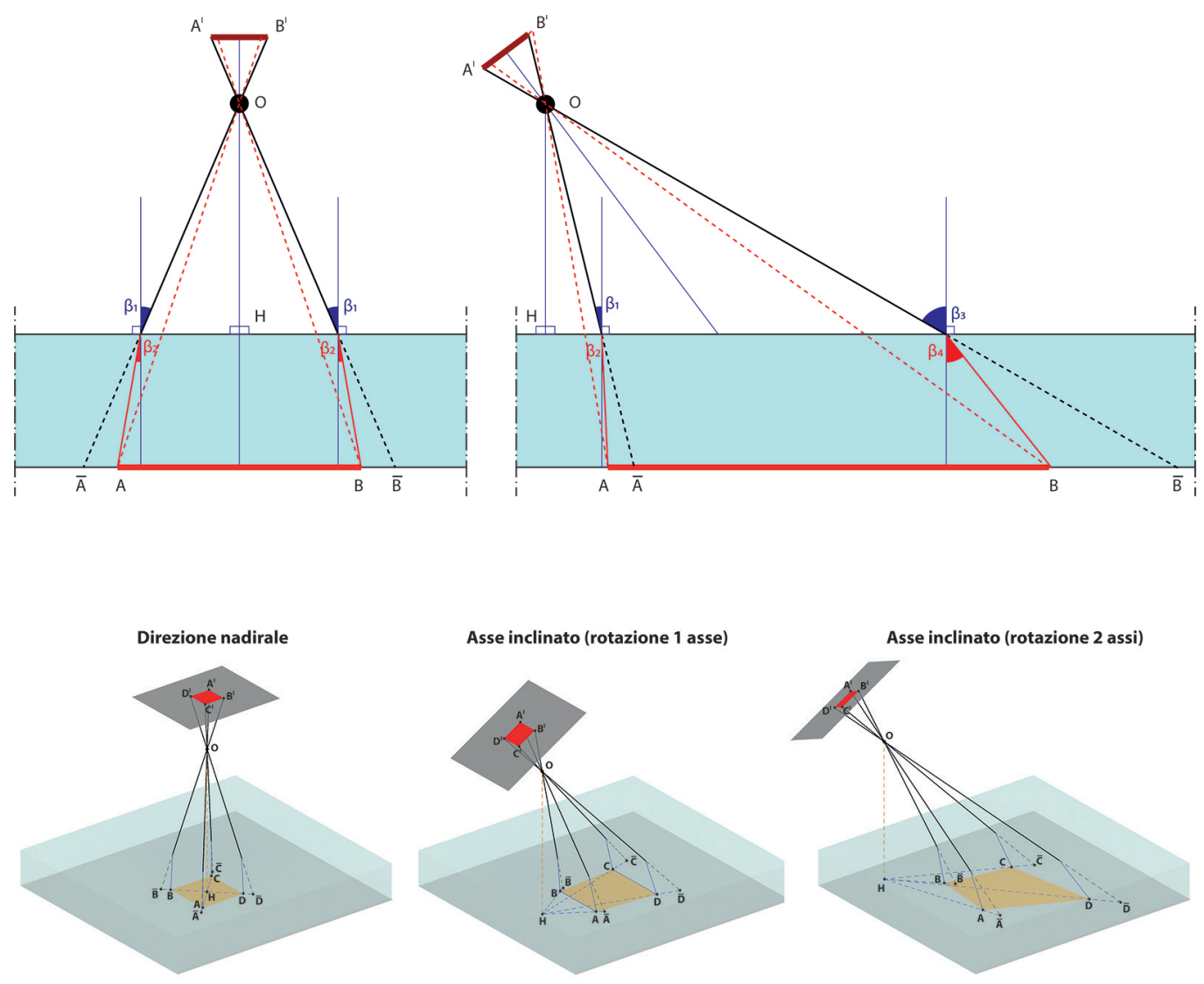

Fig. 7. In alto la

simulazione virtuale della

rifrazione di una figura

piana vista in vera forma

sul sensore della camera,

in basso le proiezioni

sul piano senza l'acqua

(rossa), con l'acqua (blu)

lo slittamento sul piano

causato dall'acqua.
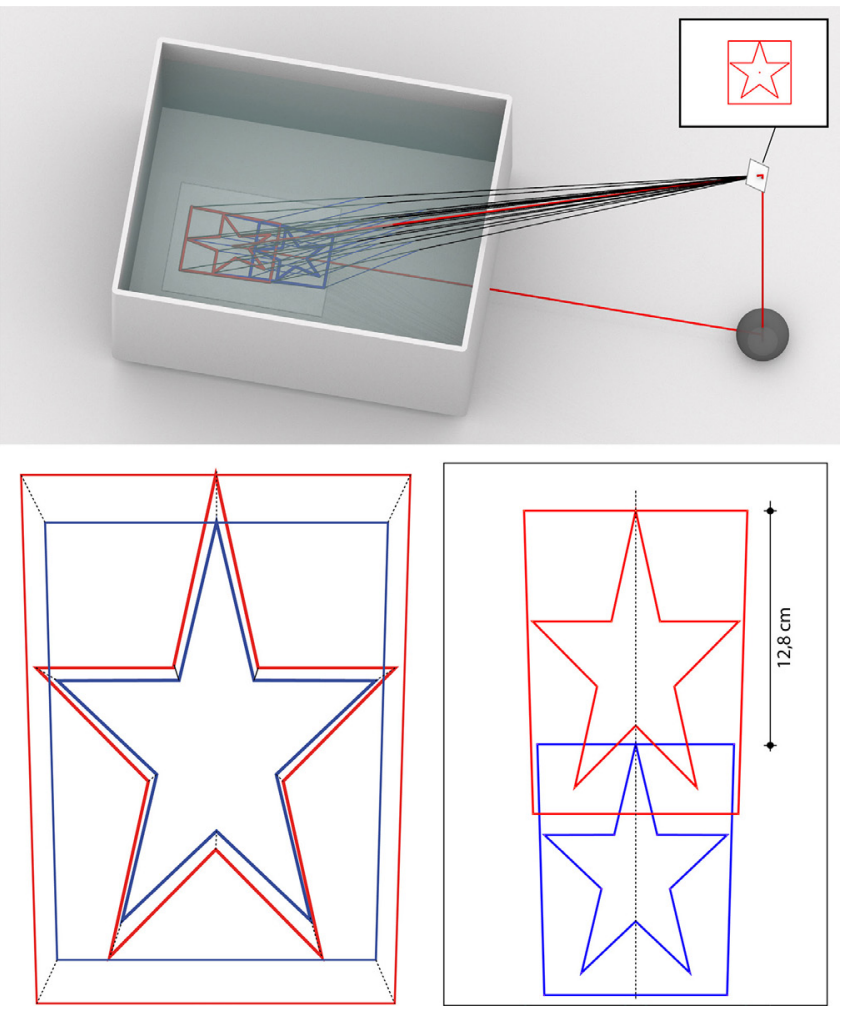

| | | | 
Fig. 8. Sperimentazione di ripresa fotografica di due target con e senza l'acqua con set-up di acquisizione e cerchi di verifica grafica della vera forma.
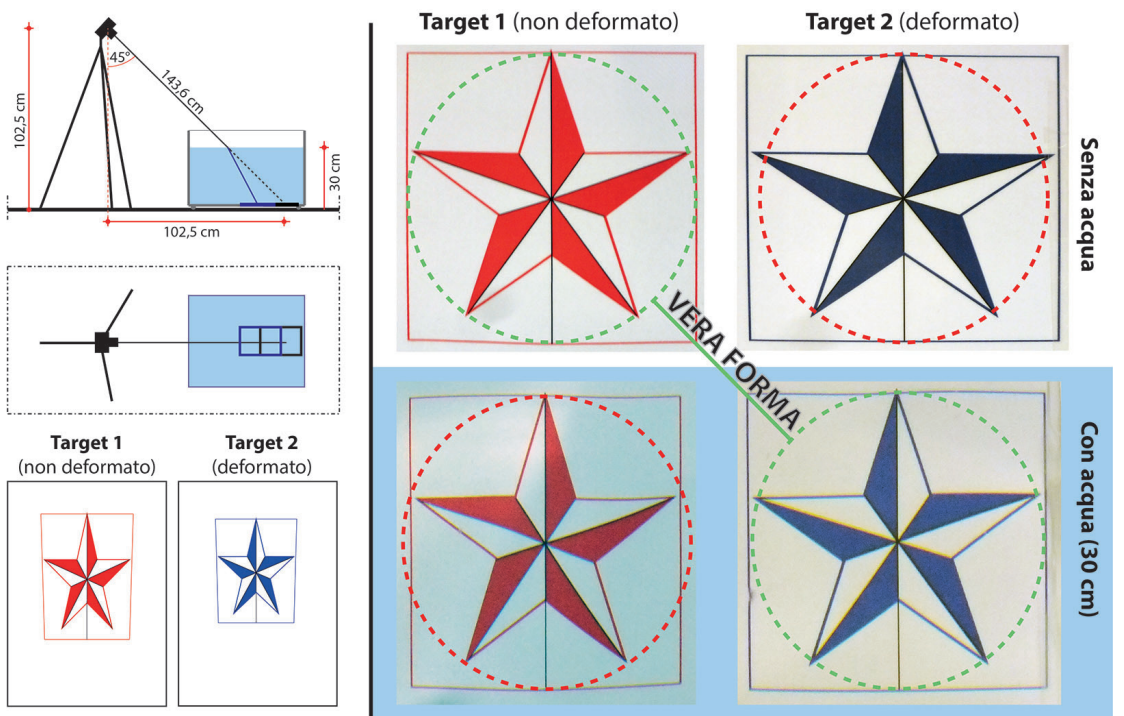

\section{Conclusioni e prospettive future}

La ricerca, partendo da una analisi sul ruolo delle immagini anamorfiche, affronta il tema della deformazione delle forme geometriche in acqua, comparando tale fenomeno a quello anamorfico. Partendo da uno studio prospettico che tenga in considerazione il comportamento fisico della rifrazione rispetto a forme geometriche nel piano, è possibile prevedere la loro deformazione in acqua da un determinato punto di vista. Questo consente da un lato di poter quantificare la trasformazione per ricostruirne il modello teorico, dall'altra definire una geometria deformata che consenta di vedere in acqua il disegno in vera forma.

I risultati raggiunti per una limitata casistica di condizioni al contorno hanno mostrato i primi risultati utili nel controllo del fenomeno, riservandosi di approfondire il tema della deformazione anche su piani verticali. La ricerca inoltre può aprire scenari trans-disciplinari, dalla fotogrammetria per il rilievo di forme geometriche immerse nell'acqua all'uso di immagini anamorfiche per fini artistici o comunicativi (fig. 9). L'acqua è un luogo parzialmente inesplorato dal rilievo e dalla rappresentazione, ma può divenire un nuovo media comunicativo attraverso il quale veicolare contenuti, creando dei percorsi percettivi e un linguaggio ancora poco indagato.

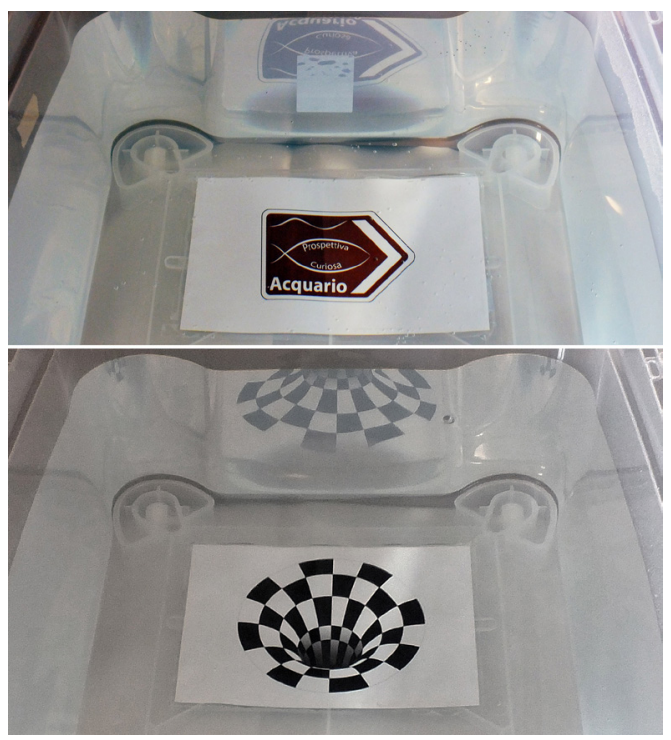




\section{Riferimenti bibliografici}

Agrafiotis P. et al. (20 I8). Underwater photogrammetry in very shallow waters: main challenges and caustics effect removal. In The International Archives of the Photogrammetry, Remote Sensing and Spatial Information Sciences, vol. XLII-2, pp. I5-22.

Andersen K. (1996). The mathematical treatment of anamorphoses from Piero della Francesca to Niceron. In History of Mathematics: States of the Art. Flores quadrivii - Studies in the Honor of Christoph J. Scriba, pp. 3-28.

Andersen K. (2007). The Geometry of an Art. The History of Perspective from Alberti to Monge. New York: Springer-Verlag.

Baltrušaitis J. (2004). Anamorfosi o Thaumaturgus opticus (Traduzione di Anna Bassan Levi). Piero Bertolucci. Milano: Adephi.

Beveer J. (2010). Pavement Chalk Artist:The Three-dimensional Drawings of Julian Beever. Richmond Hill: Firefly Books Ltd.

Collins L.D. (1992). Anamorphosis and the Eccentric Observer: Inverted Perspective and Construction of the Gaze. In Leonardo ( ${ }^{\circ}$ parte), n. 25, pp. 73-82

De Rosa A. (2006). L'apocalisse dell'ottica. Le anamorfosi gemelle di Emmanuel Maignan e di Jean François Niceron a Trinità dei Monti a Roma. In Ikhnos, n. 47, pp. 43-82.

De Rosa A., D'Acunto G. (2002). La vertigine dello sguardo. Tre saggi sulla Rappresentazione Anamorfica. Venezia: Cafoscarina Edizioni.

Di Lazzaro P., Murra D. (20 I3). L'Anamorfismo tra arte, percezione visiva e "Prospettive bizzarre". In ENEA, n. 5, pp. 7-25.

Di Paola F. et al. (20 I5). Anamorphic Projection: Analogical/Digital Algorithms. In Nexus Netw J., n. I7, pp. $253-285$.

Gardner M. ( | 975). Mathematical games, The curious magic and anamorphic art. In Scientific American, n. 232 (I), pp. I I 0 - I I 7.

Hunt J.L. et al. (2000). Anamorphic Images. In American Journal of Physics, n. 68 (3), pp. 232-23. <https://doi.org/ I0.1 I I9/I. I 9406> Illusion: Nothing is as it seems. 2013. Official Website of the Exhibition. <https://dublin.sciencegallery.com/illusion> (accessed 2021 Febraury |8)

Maas Hans-G. (2015). On the Accuracy Potential in Underwater/Multimedia Photogrammetry. In Sensors, n. I5, pp. I8I4018152.

Menna F. et al. (2018). Improving underwater accuracy by empirical weighting of image observations. In The International Archives of the Photogrammetry, Remote Sensing and Spatial Information Sciences, vol. XLII-2, pp. 699-705.

Nicéron J. F. (2016). La perspective curieuse. Magie artificielle des effets merveilleux de l'optique, vision directe. Paris: Hachette Livre-Bnf [Prima ed. La perspective curieuse. Magie artificielle des effets merveilleux de l'optique, vision directe. Chez Pierre Billaine 1638].

Symeonidou I. (20 I 6). Anamorphic Experiences in 3D Space: Shadows, Projections and Other Optical Illusions. In Nexus Netw J., n. 18, pp. 779-797

Walker J. ( 198 I). The amateur scientist: anamorphic pictures. In Scientific American, n. 245 (I ), pp. I 76- I 87.

Wright L. (1983). Perspective in perspective. Londra: Routledge Kegan \& Paul.

Zolla E. (1996). La nube del telaio. Ragione e irrazionalità tra Oriente e Occidente. Milano: Mondadori.

\section{Autore}

Michele Russo, Sapienza Università di Roma,m.russo@uniromal.it

Per citare questo capitolo: Russo Michele (202I). La prospettiva curiosa in acqua: un nuovo linguaggio anamorfico/The curious perspective in water: a new anamorphic language. In Arena A., Arena M., Mediati D., Raffa P. (a cura di). Connettere. Un disegno per annodare e tessere. Linguaggi Distanze Tecnologie. Atti del $42^{\circ}$ Convegno Internazionale dei Docenti delle Discipline della Rappresentazione/Connecting. Drawing for weaving relationship. Languages Distances Technologies. Proceedings of the $42^{\text {th }}$ International Conference of Representation Disciplines Teachers. Milano: FrancoAngeli, pp. $1105-1122$ 


\title{
The Curious Perspective in Water: a New Anamorphic Language
}

\author{
Michele Russo
}

\section{Abstract}

The representation of geometric shapes in the water and their visual perception involves different knowledge, ranging from physics to optics, from geometry to image perception. The geometric deformation, although related to the physical phenomenon of refraction, has several analogies with anamorphic images: on the one hand, the dynamic variation of shape as a function of the point of view, and on the other hand, the search for the correct view and the relative communicative role. Through a critical analysis of the anamorphic images' development in history up to the present day, the research lays the first step to study the geometric criteria of transforming flat geometric shapes in the water. The geometric principle that links the original shape and its deformed perception is simulated and analysed, proposing images that foresee the water deformation effect from a particular point of view. The research aims to define experimentally a method of constructing anamorphic images in water, showing the physical and perceptual phenomenon's integration. The critical analysis of the obtained results can open new trans-disciplinary research scenarios.

\section{Keywords}

perspective, anamorphosis, water, refraction, communication.

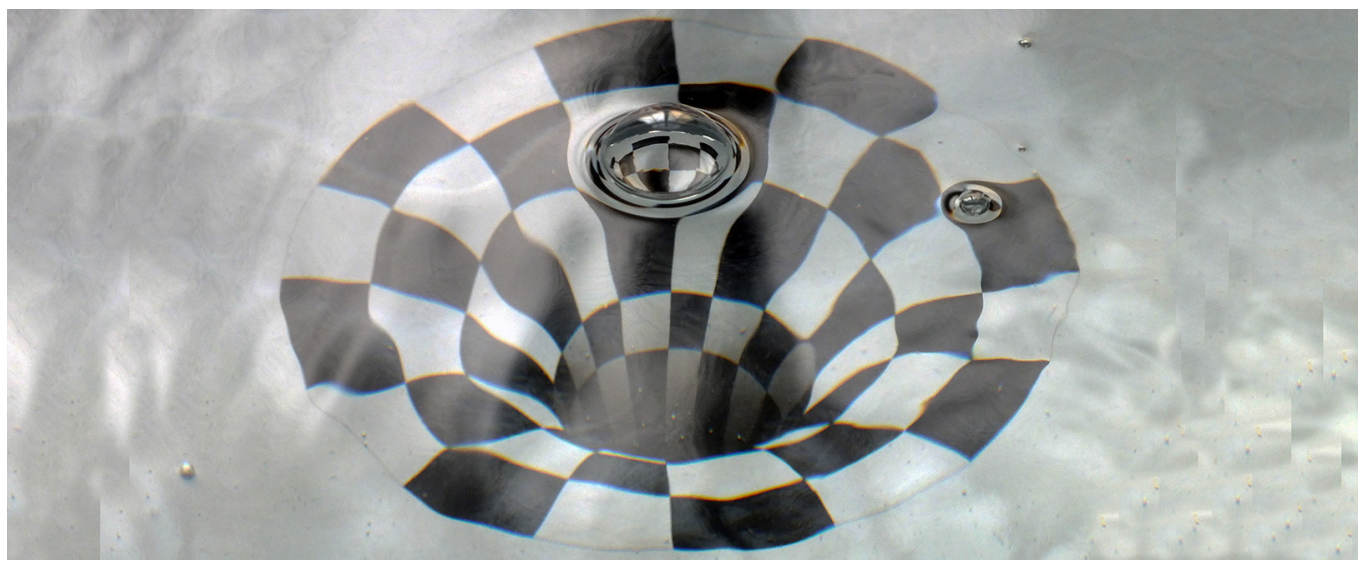




\section{Introduction}

"There is a fountain in Granada where visitors are told the story of an Arab caliph who was about to appoint a Grand Vizier: to choose he invited the candidates to identify an object resting or floating in shallow water. All but one immediately said it was an orange. However, one first picked it up and identified it as half an orange and got the promotion." [Wright 1983, p. 24] The special relationship between geometric shapes in the water and man determines lability in perceptual vision. It is based on a figurative and mental system that, if subverted, induces visual incoherence, transporting to a world in which the dichotomy between rule and disorder coexists [Zolla 1996, p. 128]. This alteration presents analogies with the deformation of geometric shape operated by anamorphosis. This latter shifts the attention on the one hand towards the "correct vision" and the "gaze subjectification," on the other hand stimulating curiosity and kinetic fruition in space in search of the decisive interpretative angle [De Rosa, D'Acunto 2002].

This itinerant process represents the primary tool for analysing deformative phenomena and the keystone for understanding and translating into a single controlled and predictable spatiality. Anamorphic images establish a special relationship with urban or architectural space, transforming it into a narrating place, usable and enjoyed according to a directional dynamic. Their increasing diffusion as a communication tool and their hybridization with the aquatic world can lead to a new language. Besides, it becomes essential to understand better the role of the anamorphic images and the projective process outside and inside the water. A short description of the anamorphosis development, with particular attention to direct anamorphosis, is suggested. The experimentation highlights the geometric and optical relationships of flat anamorphic images in water, starting a path of analysis of the language of submerged geometric shapes and their way of perception, anticipating possible trans-disciplinary scenarios.

Fig. I. Qualitative diagram of anamorphosis development throughout history concerning the role, artistic forms, and diffusion.

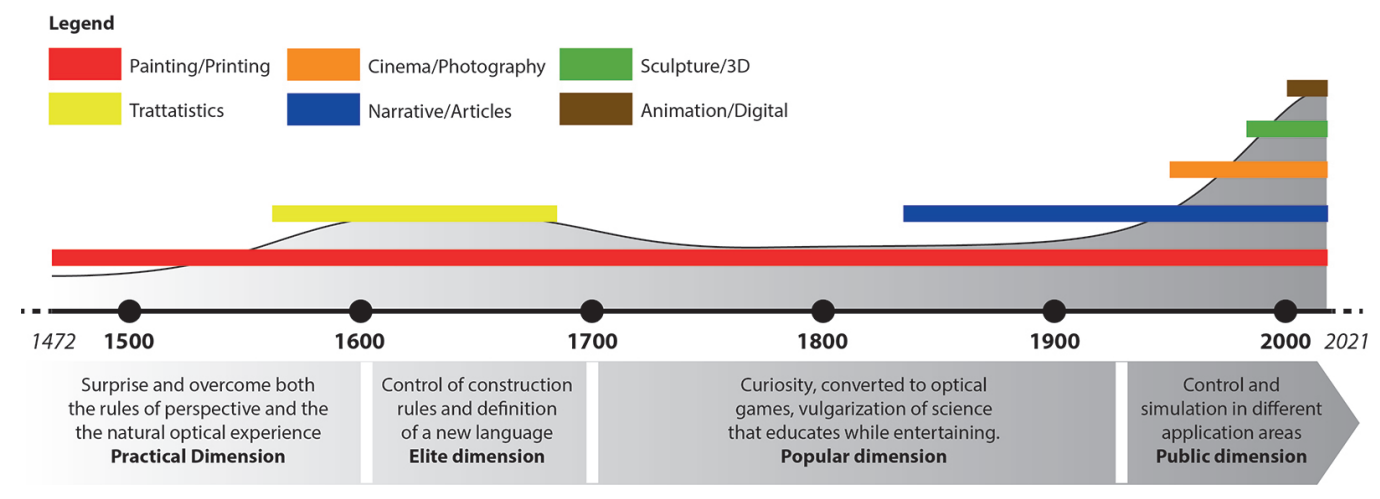

\section{Anamorphosis as a communication tool over time}

The term anamorphosis, of Greek derivation, is composed of the suffix ávó; (upward, backward, return toward) and $\mu$ opфń (form). It refers to a geometric transformation process related to the linear perspective rules (perspectiva artificialis), both in genesis and relative fruition [Gardner 1975, Walker 198I, Hunt et al. 2000, Andersen 2007]. It is based on the principle of monocular vision, following the 'visual cone' of classical perspective, assuming a subjective point of view that reinscribes the source of vision in the physical body [Collins 1992. p. 73].The resulting images are apparently distorted, revealing their correct geometric configuration according to a prefixed point of observation (direct perspective anamor- 
phosis) or through a convex mirror surface reflection (catoptric anamorphosis) [Andersen 1996]. In representation history, they are defined as a virtuosic expression of the perspective laws, concerning which they constitute a kind of "curious" perspective [Niceron 1638] or projective "depravity" [Baltrušaitis 1978].

In this paper, only direct perspective anamorphosis will be analysed, which exhibits optical-perceptual conditions similar to shapes in the water. The significance of anamorphic images has changed profoundly in the history of the figurative arts. From the first representations of Piero della Francesca (Pala di Brera, I472) or Leonardo's sketches (Codex Atlanticus, I5 I5), these representations have passed through different levels of optical-geometric and communicative awareness. Starting from an initial elitist communication tool, they became a scientifically recognized language (Anamorphose, Encyclopédie of Diderot and d'Alembert, I75 I) until they were applied in multiple fields in the 20th century (fig. I). The resurgence of interest in anamorphic images since the 30s defines a new cultural scenario, suggesting different communicative themes. The definition of one or more preferential points of explicit viewing allows the user to understand the artifact better while reducing its accessibility and collective perception [De Rosa 2006]. The path becomes a design objective in the work's communicative experience, offering a transformation of the form towards the system's correct vision.

Fig. 2. Perspective relations between a square in the correct shape on the picture plane $(\varpi)$ and its possible projections on different main or auxiliary planes.
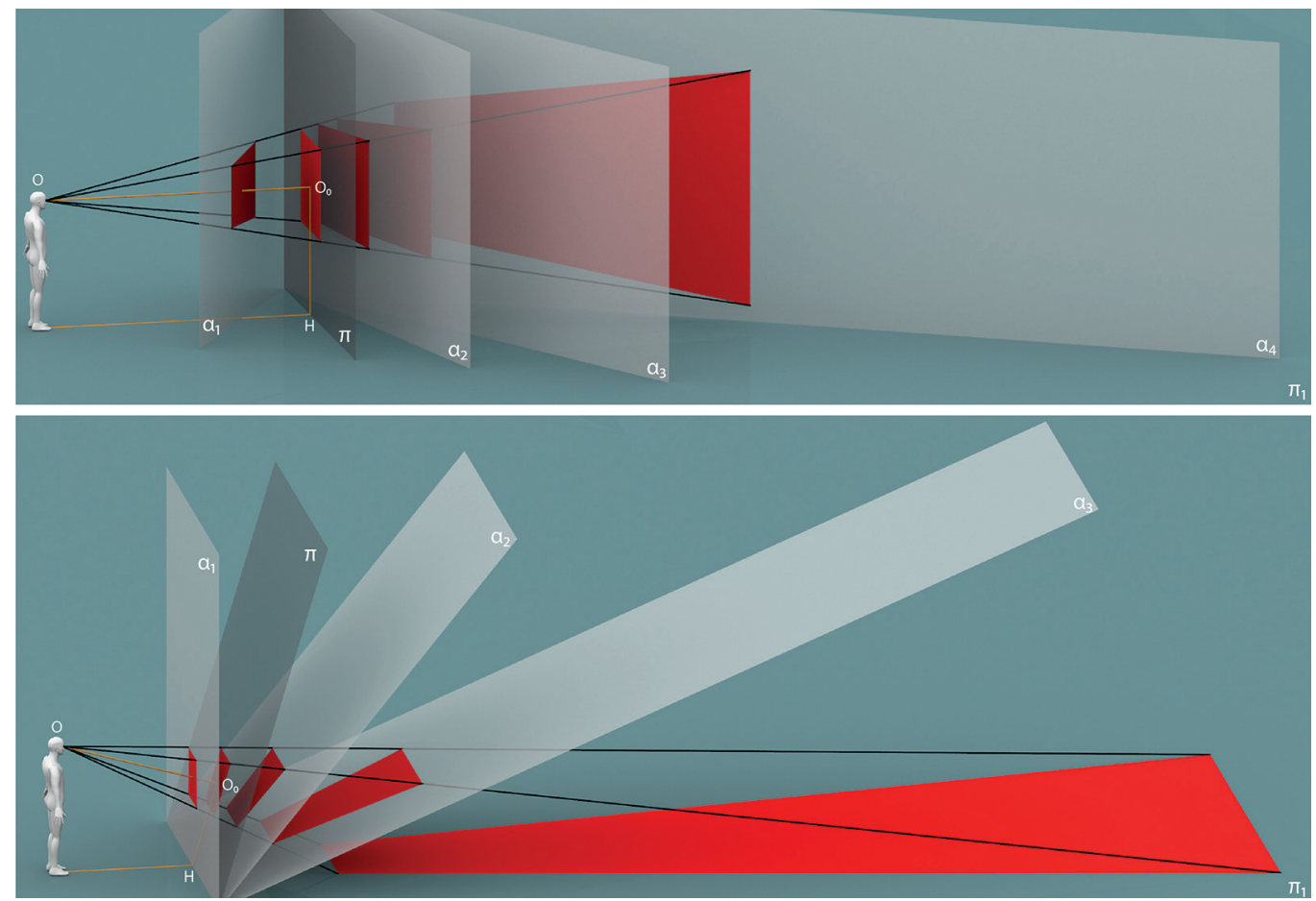

\section{Anamorphosis in actual communication media}

Anamorphic images are mainly related to project planning, industrial design, scenography, decorative and advertising activities. However complex, their application is often reduced to horizontal or vertical projections, depending on the representation scale (fig. 2).

A first example is provided by Guillaume "Saype" Legros, a specialist in land art at the territorial scale. At the urban scale, on the other hand, alongside the tracing of street and advertising signs [Di Lazzaro, Murra 20 I3], the activity of visual artists, who create a strong interaction with the illusory space of the drawing and the urban space, takes on an important role. Artists (fig. 3) include Kurt Wenner, Julian Beever [Beveer 20 I0], Manfred 
Stader, Edgar Muller, Eduardo Relero, Nikolaj Arndt, Sergio Odeith, and Leon Keer. Some of these, such as Vera Bugatti, use anamorphic painting to denounce environmental and social issues. In some cases, the anamorphosis leaves the plane, transforming itself into urban paths characterized by a dynamic perception of spatial forms, such as the Ephemeral garden by François Abélanet.

Among the vertical representations, the urban graffiti of Manuel "Peeta" di Rita represents an emblematic case, next to the use of inscriptions identifying architectural buildings, such as the Marta Herford Museum. On an architectural scale, vertical anamorphosis is predominant, given the need to convey the gaze in specific spatial directions. Felice Varini [Di Paola et al. 2015] uses simple geometric shapes to create preferential viewpoints in existing architecture, while Thomas Quinn uses anamorphic typography as a tool for directional decoration.

A particular hybridization between flat anamorphic projection and 3D space allows us to study environmental forms' conditioning on our visual perception. Examples are Ames' room (1946) and Jan Beutner's room (1975).

Moving from the plane to space, the latter becomes an expressive itinerary of the form that want to free itself, as in the works of SandorVamos, Alessandro Diddi, or Alessandro Panzetti. The forms in the space decompose and recompose with different meanings, as in the works of Michael Murphy, Giovanni Re, or Jonty Hurwitz, who works on the themes of optics [ILLUSION 20 I 3], expressing significant ambivalent, as in the Ambigram Sculpture of Markus Raetz [Symeonidou 2016].
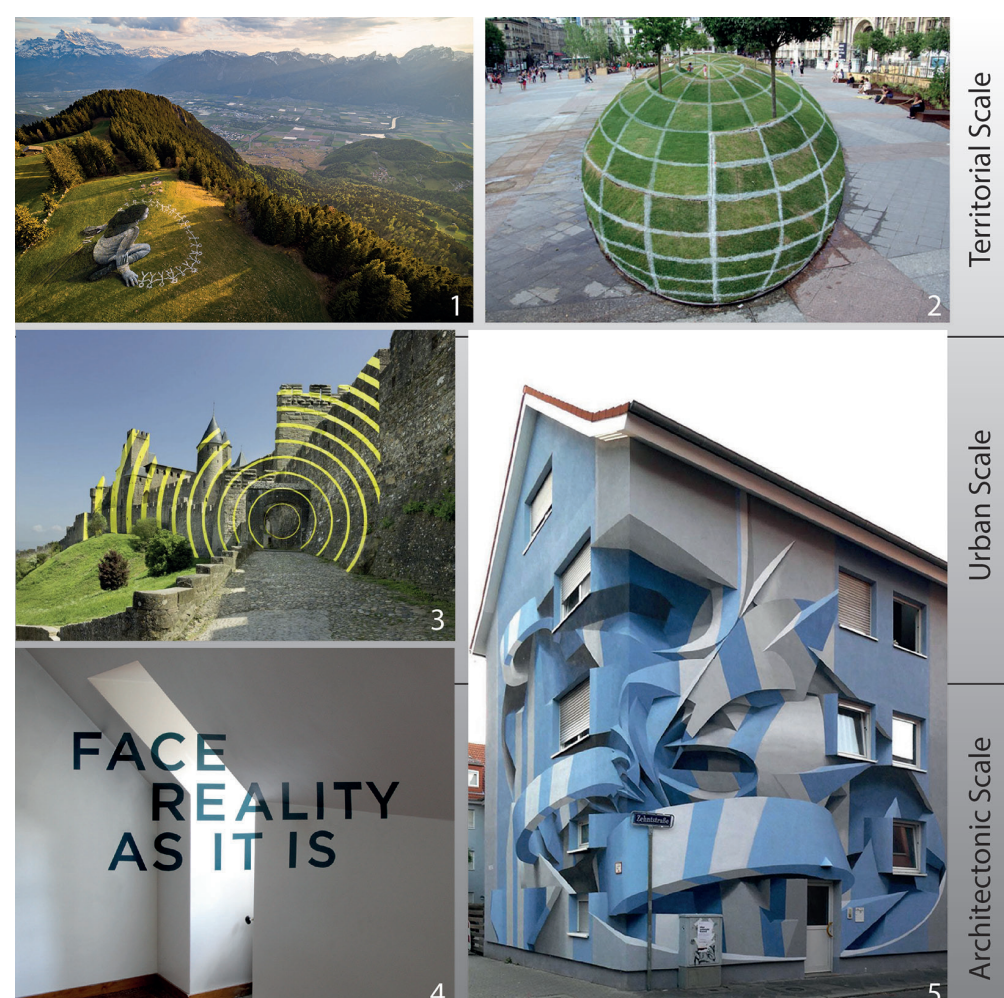

Fig. 3. Contemporary anamorphic works that highlight a language in transformation as a scal function: G. Legros, Leysin (I): F.Abélanet Hôtel de Ville, Paris (2): FVarini Varcasson (2); F.Varini, Carcassonne (3);T. Quin Chicago (4); M. Di Rita, (6); M. Murphy (7).
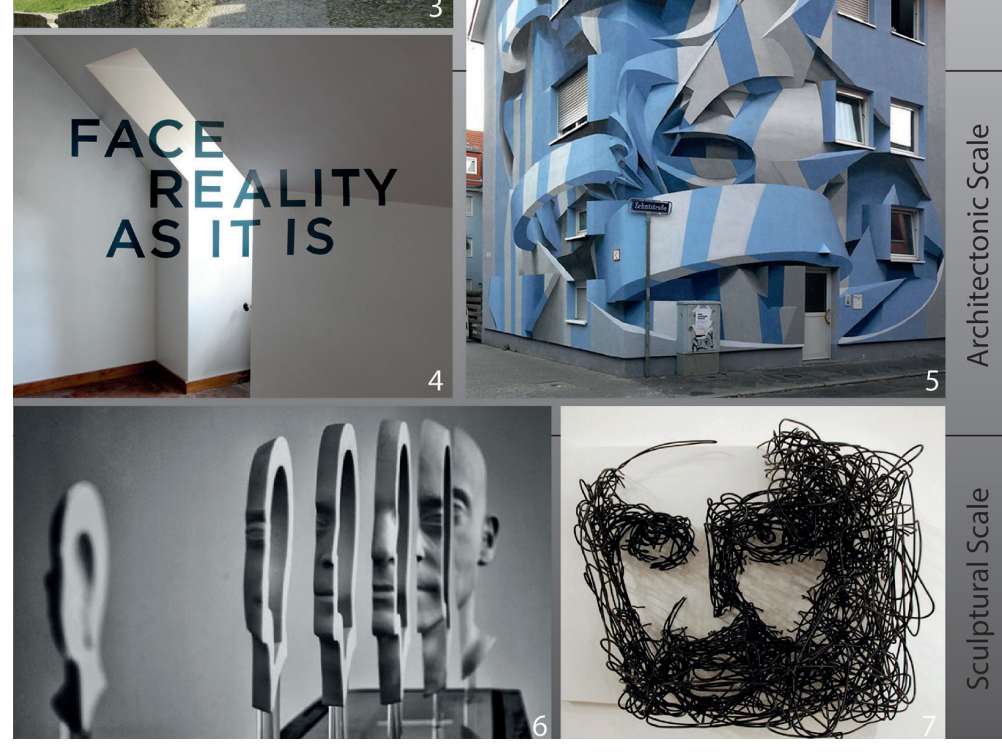


\section{Anamorphic representation and water medium}

The relationship between water and anamorphic images is little studied both geometrically and perceptually. However, water's dynamism and its role as a 'dividing plane' between two different realities make it a privileged subject for anamorphosis, as seen in street artworks (fig. 4). The recent anamorphic installation Wave (d'strict study) in the centre of Seoul, for example, simulates the dynamics of the fluid according to a given point of view through a giant screen.

The lack of anamorphic image used in the water may lie both in the installations and perspective phenomenon control. Regarding the latter, the first studies date back to the 50s, often limited to the geometric analysis through a single homogeneous medium. For the past five years, some research has been undertaken on the geometric relationships between projective rays passing through different materials [Maas 20I5, Menna 2018] and environmental conditions [Agrafotis 20l8]. These studies represent an essential starting point for the geometric analysis of shapes immersed in a liquid and creating anamorphic images in water.
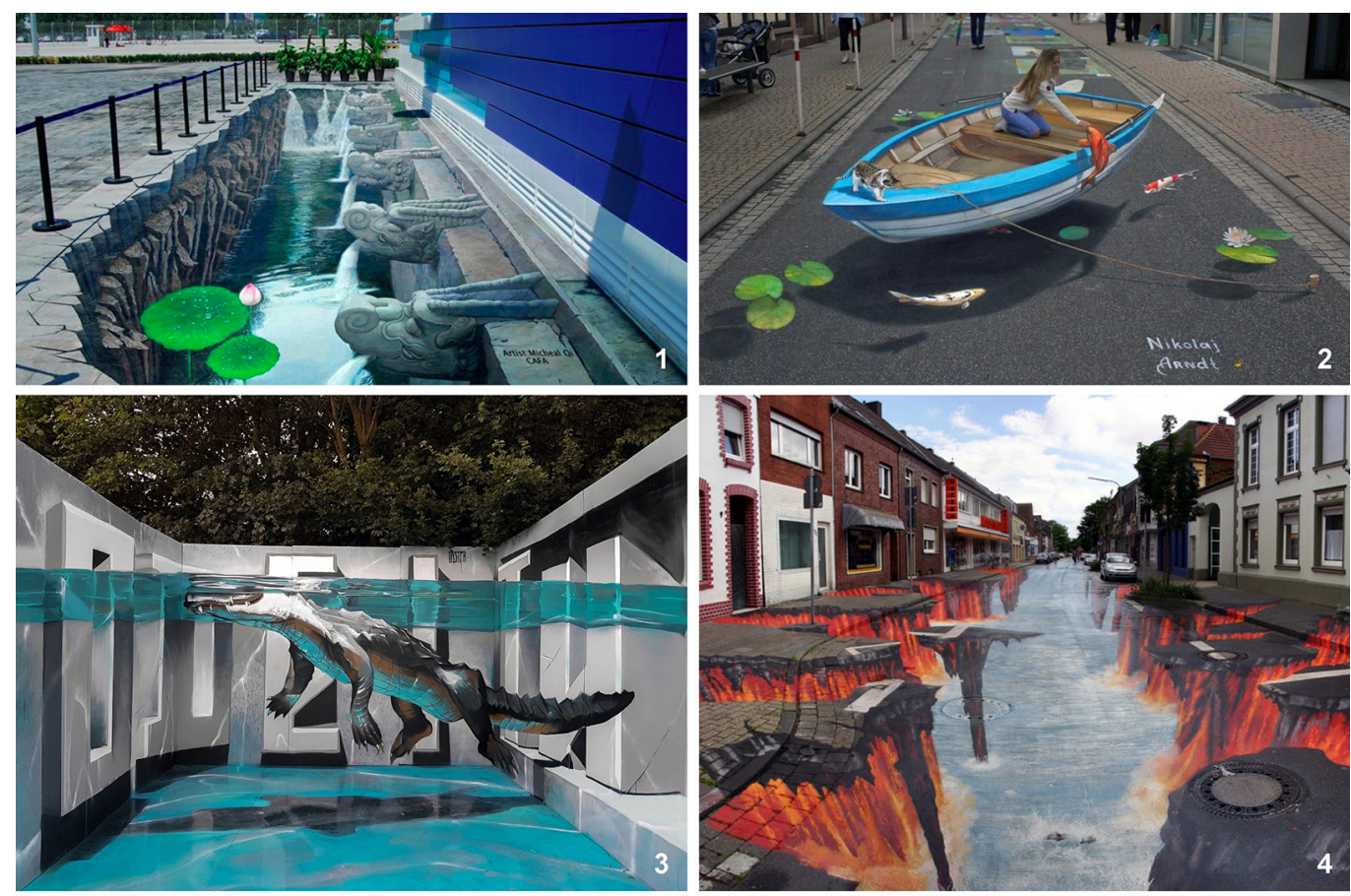

Fig. 4. Relation between anamorphic works and water: painting in Barcelona by M. Qi Cafa (1), painting by N.Arndt (2), painting for Upfest 2018 by S. Odeith (3) painting in Geldern by E. Muller (4), painting in Honolulu (Hawaii) by Pugh (5) Wave installion in Seoul by Studio d'strict
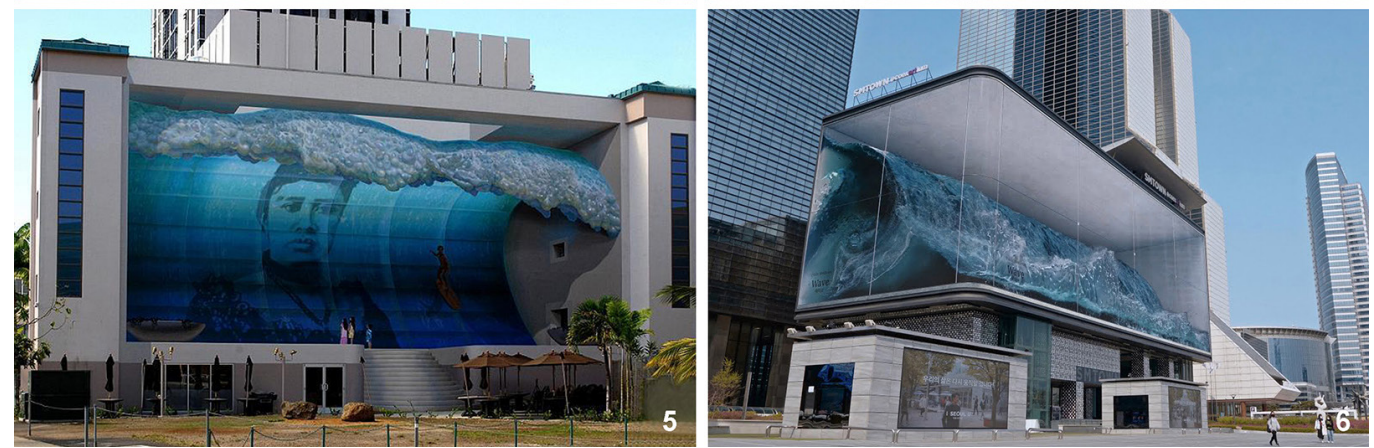


\section{Experimentation}

In this experimentation, the anamorphic image assumes the dual role of perceptual lens and process verification system. By imposing the horizontal position of the images in the water and an oblique vision axis, the anamorphic relationship is recreated concerning a single centre of the camera's perspective (fig. 2). In the two-dimensional geometric analysis (fig. 5), the refraction of rays according to Snell's law is calculated, considering the value of air (1.000269) and water (1.334) and applying the following equation:

$$
\frac{\sin \widehat{\beta_{1}}}{\sin \widehat{\beta_{2}}}=1,334
$$

In 3D space (fig. 6), it must be considered that each apparent point (point seen out of the water) undergoes a translation on the plane and along the line connecting the apparent point with the vertical projection $(\mathrm{H})$ of the nodal centre of the camera on the plane shared with the figure.

Starting from this a priori geometric analysis, an experimental phase based on simulation and observation of the phenomenon is initiated, assuming the following simplifications:

I. The reference or anamorphic image lies on a horizontal plane $\left(\varpi_{1}^{\prime}\right)$;

2. The observer experiences anamorphosis using a camera, ignoring binocular vision.

3. Anamorphosis occurs from a single point $(O)$, the camera nodal centre, intended as the observer's 4. preferred point of view and the perspective projection centre.

The camera axis is nadiral to the water plane or rotated $45^{\circ}$, defining the direction of view.

The experimentation takes place in two distinct phases: virtual simulation of the phenomenon and real analysis of the anamorphosis in water. In the first step, the perspective relationship between the star shape, in the correct form on the frame plane (sensor), and its two projections, obtained both on the bottom plane of an empty/filled container with $30 \mathrm{~cm}$ of water, is represented in a 3D modeling environment (fig. 7). The following simplifications justify a reduced transformation between the two projections:

- the rotation of a single axis of the picture plane;

- the perpendicular projection of the axis concerning the figure;

- the optical axis passing through the barycentre of the figure.

On the other hand, the plane's shift between the two figures, equal to $12.8 \mathrm{~cm}$, is evident (fig. 7).

Based on the process simulation, a real test is carried out. The simulated geometries without water (red target) and water (blue target) are printed and introduced in the container, first empty and then filled with $30 \mathrm{~cm}$ of water. A photographic campaign with a Finepix HS2O EXR camera, a focal length of $14 \mathrm{~mm}$, has been planned, according to specific acquisition parameters (fig. 8). Comparing the images obtained with and without water shows that target I without water and target 2 with water reproduce the correct geometric shape in the sensor, verified by the construction of a verification circle, while the others show different types of deformation. Therefore, it is shown that the virtual simulation is correct and that, given specific boundary conditions, it is possible to obtain an anamorphosis in water.

\section{Conclusions and future prospects}

The research, starting from an analysis on the role of anamorphic images, addresses the deformation of geometric shapes in the water, comparing this phenomenon to the anamorphic one. From a perspective study that considers the physical behaviour of refraction concerning geometric shapes in the plane, it is possible to predict their deformation in 
Fig. 5. Relationship between the shape acquired by the camera (AlBI), the projective rays of center $\mathrm{O}$ (nodal center of the camera), and the shape in water $(A B)$ in nadiral (left) and oblique concerning

Fig. 6. Geometric diagrams on camera-shape

projection relationship as a function of camera axis rotation.
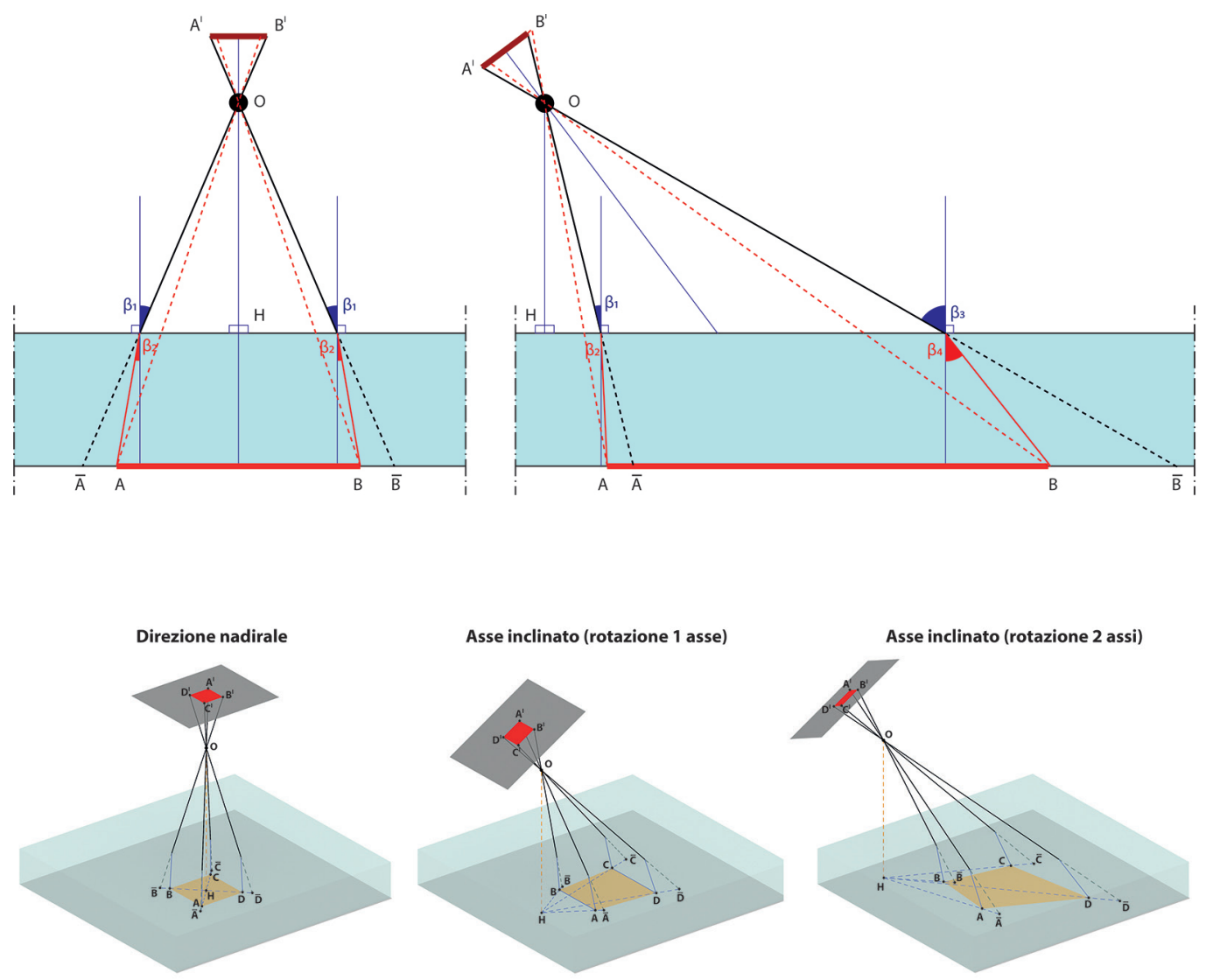

Fig. 7. Top is the virtual simulation of a plane figure the refraction seen in the correct shape on the camera sensor; bottom are the projections of the shape in the plane without the water (red) with the water (be) and the shift water (blue) and the sh in the plane given by the in the plane given by the
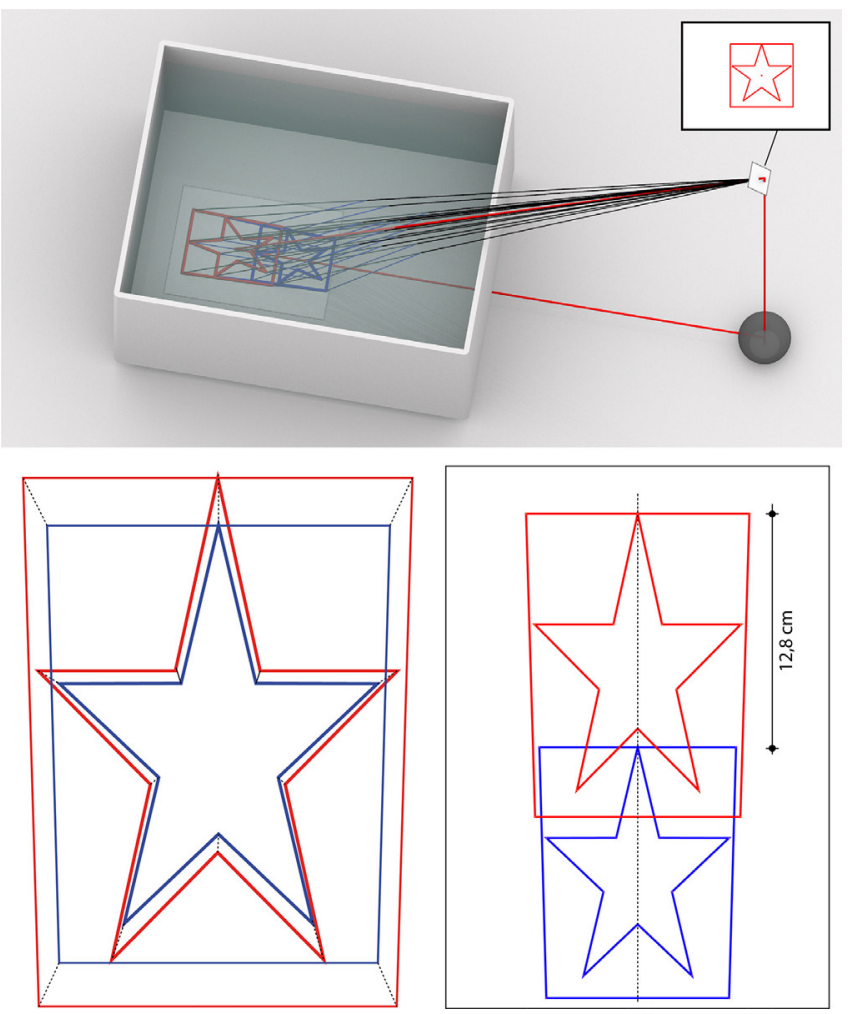
Fig. 8. Experimentation of photographic shooting of two targets with and without water with acquisition set-up and graphical verification circles of the correct shape.
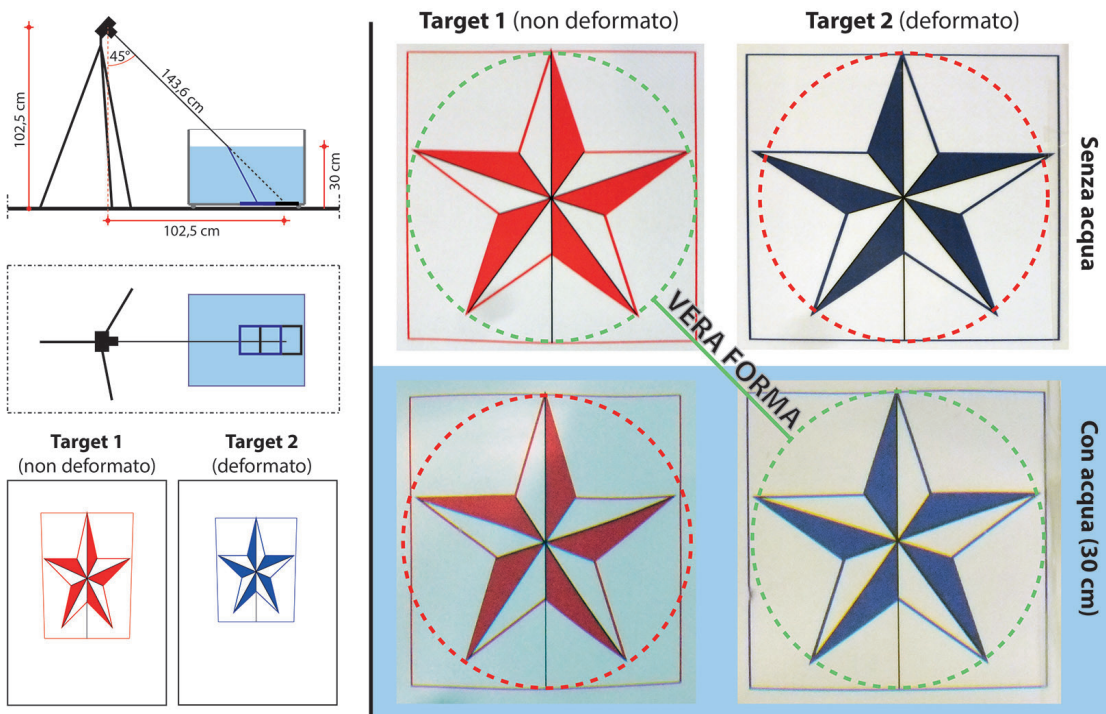

water from a given point of view. On the one hand, it allows being able to quantify the transformation to reconstruct the theoretical model. On the other hand, defining a deformed geometry allows seeing the design in the correct shape in the water.

The results achieved, based on limited operative conditions, have shown the first useful results in controlling the phenomenon, reserving to investigate the deformation issue on vertical planes. This research can open trans-disciplinary scenarios both in the photogrammetry and artistic field (fig. 9). Water is a place partially unexplored by survey and representation. However, it can become a new communicative medium to convey content, creating perceptual paths and a language few investigated.
Fig. 9. Two examples of the application of controlled geometric shapes in water: top an example of wayfinding, bottom an application of optical illusions.

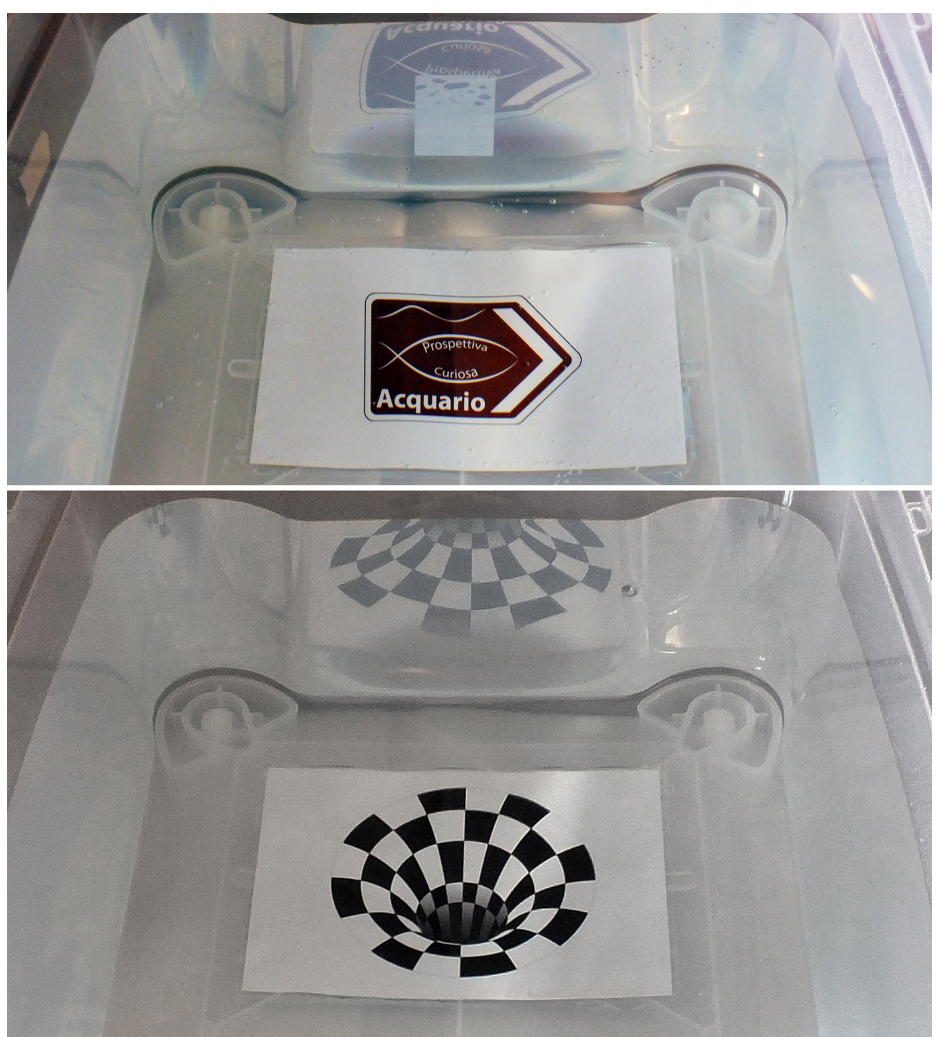




\section{References}

Agrafiotis P. et al. (20 I8). Underwater photogrammetry in very shallow waters: main challenges and caustics effect removal. In The International Archives of the Photogrammetry, Remote Sensing and Spatial Information Sciences, vol. XLII-2, pp. I5-22.

Andersen K. (1996). The mathematical treatment of anamorphoses from Piero della Francesca to Niceron. In History of Mathematics: States of the Art. Flores quadrivii - Studies in the Honor of Christoph J. Scriba, pp. 3-28.

Andersen K. (2007). The Geometry of an Art. The History of Perspective from Alberti to Monge. New York: Springer-Verlag.

Baltrušaitis J. (2004). Anamorfosi o Thaumaturgus opticus (Traduzione di Anna Bassan Levi). Piero Bertolucci. Milano: Adephi.

Beveer J. (2010). Pavement Chalk Artist:The Three-dimensional Drawings of Julian Beever. Richmond Hill: Firefly Books Ltd.

Collins L.D. (1992). Anamorphosis and the Eccentric Observer: Inverted Perspective and Construction of the Gaze. In Leonardo ( ${ }^{\circ}$ parte), n. 25, pp. 73-82

De Rosa A. (2006). L'apocalisse dell'ottica. Le anamorfosi gemelle di Emmanuel Maignan e di Jean François Niceron a Trinità dei Monti a Roma. In Ikhnos, n. 47, pp. 43-82.

De Rosa A., D’Acunto G. (2002). La vertigine dello sguardo. Tre saggi sulla Rappresentazione Anamorfica. Venezia: Cafoscarina Edizioni.

Di Lazzaro P., Murra D. (20 I 3). L'Anamorfismo tra arte, percezione visiva e "Prospettive bizzarre". In ENEA, n. 5, pp. 7-25.

Di Paola F. et al. (20 I5). Anamorphic Projection: Analogical/Digital Algorithms. In Nexus Netw J., n. I7, pp. $253-285$.

Gardner M. (1975). Mathematical games, The curious magic and anamorphic art. In Scientific American, n. 232 ( I ), pp. I I 0 - I I 7.

Hunt J.L. et al. (2000). Anamorphic Images. In American Journal of Physics, n. 68 (3), pp. 232-23. <https://doi.org/ I 0.I I I9/I. I 9406> Illusion: Nothing is as it seems. 2013. Official Website of the Exhibition. <https://dublin.sciencegallery.com/illusion> (accessed 2021 Febraury 18)

Maas Hans-G. (2015). On the Accuracy Potential in Underwater/Multimedia Photogrammetry. In Sensors, n. I5, pp. I8I4018152.

Menna F. et al. (20 I8). Improving underwater accuracy by empirical weighting of image observations. In The International Archives of the Photogrammetry, Remote Sensing and Spatial Information Sciences, vol. XLII-2, pp. 699-705.

Nicéron J. F. (2016). La perspective curieuse. Magie artificielle des effets merveilleux de l'optique, vision directe. Paris: Hachette Livre-Bnf [Prima ed. La perspective curieuse. Magie artificielle des effets merveilleux de l'optique, vision directe. Chez Pierre Billaine 1638].

Symeonidou I. (20 I 6). Anamorphic Experiences in 3D Space: Shadows, Projections and Other Optical Illusions. In Nexus Netw J., n. 18, pp. 779-797.

Walker J. (I98I). The amateur scientist: anamorphic pictures. In Scientific American, n. 245 ( I), pp. I76- I 87.

Wright L. (1983). Perspective in perspective. Londra: Routledge Kegan \& Paul.

Zolla E. (1996). La nube del telaio. Ragione e irrazionalità tra Oriente e Occidente. Milano: Mondadori.

\section{Author}

Michele Russo, Sapienza Università di Roma,m.russo@uniromal.it

To cite this chapter. Russo Michele (2021). La prospettiva curiosa in acqua: un nuovo linguaggio anamorfico/The curious perspective in water: a new anamorphic language. In Arena A., Arena M., Mediati D., Raffa P. (a cura di). Connettere. Un disegno per annodare e tessere. Linguaggi Distanze Tecnoogie. Atti del $42^{\circ}$ Convegno Internazionale dei Docenti delle Discipline della Rappresentazione/Connecting. Drawing for weaving relationship. Languages Distances Technologies. Proceedings of the $42^{\text {th }}$ International Conference of Representation Disciplines Teachers. Milano: FrancoAngeli, pp. I I $05-1$ I 22. 